\title{
Keragaman Pangan dan Status Gizi Pada Anak Balita di Kelurahan Pasirkaliki Kota Cimahi
}

\author{
Dietary Diversity and Nutrional Status of Under Five Children \\ in Pasirkaliki Ditrict, Cimahi
}

\author{
WITRI PRIAWANTIPUTRI*, MIMIN AMINAH \\ Jurusan Gizi, Politeknik Kesehatan Kementrian Kesehatan Bandung Kampus Gunung Batu, Cimahi 40514,
Indonesia
}

Diterima 19 Februari 2020/Disetujui 7 November 2020

\begin{abstract}
Dietary diversity refers to an increase in the variety of foods across and within food groups capable of ensuring adequate intake to promote a good nutritional status. The purpose of this study was to determine the relationship of food diversity with the nutritional status of children under five in Kelurahan Pasirkaliki Kota Cimahi. A crosssectional study with a simple random sampling method was conducted among 79 households having under five age children. Individual food diversity was measured using a dietary diversity score through questionnaire from FANTA Dietary Diversity Score Indicator Guide. Nutritional status of children under five measured by anthropometric measurement with indicator Z-score of WHZ, WAZ, and HAZ. The analysis was carried out by Chi square test and fisher's exact. The average age of children under five is 31 months consisting of 43 boys (54.4\%) and $36(45.6 \%)$ girls. The prevalence of wasting children was $3.8 \%$, stunting $21.5 \%$, and underweight $10.1 \%$. As many as $56(70.9 \%)$ children consume diverse foods. There is no relationship between food diversity with nutritional status $(p>0.05)$. Consumption of diverse food with appropiate amount of food portions are recommended for children under five years to get optimal nutritional status.
\end{abstract}

Key words: Dietary diversity, nutritional status, children under 5 years

\section{PENDAHULUAN}

Pertumbuhan anak diakui secara internasional sebagai indikator penting dari status gizi dan kesehatan pada suatu populasi (BAPPENAS dan UNICEF 2017). Status gizi balita pada suatu negara merupakan salah satu indikator utama pembangunan dan sebagai prasyarat untuk kemajuan sosial ekonomi masyarakat dalam jangka panjang (Onis 2000). Hasil Pemantauan Status Gizi (PSG) Tahun 2017 menunjukkan prevalensi balita gizi kurang di Indonesia sebesar $17.8 \%$, balita pendek $29.6 \%$, dan balita kurus 9.5\%. Berdasarakan klasifikasi World Health Organization (WHO) Indonesia memiliki masalah kesehatan akut dan kronik (Kemenkes RI 2017). Hal ini berkaitan dengan prevalensi balita pendek yang masih diatas $20 \%$ dan prevalensi balita kurus diatas $5 \%$.

Kekurangan gizi pada masa balita dapat meningkatkan resiko terhadap tingkat kecacatan penyakit tidak menular dan kematian di masa yang akan datang. Bagi suatu negara tingginya tingkat

*Penulis korespondensi:

E-mail: witri.priawantiputri@staff.poltekkesbandung.ac.id kurang gizi dapat menghambat pertumbuhan ekonomi di masa depan dengan berkurangnya potensi intelektual dan fisik dari generasi penerus (Taruvinga 2013).

Status gizi disebabkan oleh dua penyebab langsung yaitu asupan zat gizi dan adanya penyakit infeksi (UNICEF 2011). Asupan zat gizi seseorang dapat dipenuhi dengan mengkonsumsi makanan yang beragam. Konsumsi makanan yang beragam dapat melengkapi keunggulan susunan zat gizi jenis makanan lain sehingga diperoleh masukan zat gizi yang seimbang (Fauzia 2016).

Berdasarkan penelitian Sukma beragamnya pangan yang dikonsumsi sangat penting untuk diukur agar dapat menilai kualitas konsumsi pangan. Keragaman pangan dapat ditentukan dari item pangan yang dikonsumsi atau penjumlahan kelompok pangan yang dikonsumsi (Sukma 2014). Dietary Diversity Score (DDS) atau skor keanekaragaman pangan merupakan salah satu cara pengukuran kualitas konsumsi pangan. Menurut FAO metode DDS merupakan metode sederhana yang mudah dilakukan namun sangat efektif untuk mengukur perbedaan keragaman konsumsi pangan pada tingkat rumah tangga maupun individu (FAO 2011). 
Keragaman pangan mengacu kepada peningkatan konsumsi berbagai jenis kelompok bahan makanan yang dapat memenuhi kebutuhan zat gizi bagi kesehatan yang optimal. Tidak ada makanan yang mengandung semua nutrisi, dengan mengkonsumsi bahan makanan yang beragam diharapkan dapat memenuhi kebutuhan zat gizi seseorang (FAO 2011). Ruel mencatat bahwa keragaman pangan merupakan tantangan bagi masyarakat di negara berkembang. Pola diet di negara berkembang seperti Indonesia mengandalkan makanan pokok serealia dengan kurangnya asupan protein hewani, buah-buahan dan sayuran (Ruel et al. 2004). Pola makan masyarakat Indonesia telah bergeser dari mengkonsumsi makanan yang tinggi serat menjadi mengkonsumsi makanan yang tinggi lemak dan energi (Kemenkes RI 2014). Sebuah penelitian di Bangladesh menunjukkan adanya hubungan positif antara keragaman pangan dengan status gizi anak terutama dengan indikator $\mathrm{TB} / \mathrm{U}$ (Rah et al. 2010). Penelitian lainnya di Indonesia menunjukkan adanya hubungan antara keragaman pangan dan pendapatan (jumlah dan jenis) dengan Z-skor $\mathrm{BB} / \mathrm{TB}$ sehingga hal ini dapat digunakan sebagai prediktor status gizi (Wirawan dan Rahmawati 2016). Kebutuhan zat gizi anak balita meningkat karena masih berada pada masa pertumbuhan cepat dan aktivitasnya semakin meningkat. Konsumsi makanan yang beragam diharapkan dapat menunjang kebutuhan zat gizi yang diperlukan oleh tubuh untuk mencapai pertumbuhan yang optimal (Susilowati dan Kuspriyanto 2016).

Prevalensi Balita Gizi buruk berdasarkan hasil Bulan Penimbangan Balita (BPB) tahun 2013 di Kota Cimahi BB/TB $(0.07 \%)$ BB/U $(0,47 \%)$ berada dibawah Target SPM $(<1 \%)$, hal ini berarti menunjukan prevalensi gizi buruk masih ada dalam batas normal, walaupun demikian tetap perlu penanganan yang lebih serius karena dalam satu wilayah jika ada kasus gizi buruk walaupun hanya satu orang maka merupakan Kejadian Luar Biasa (KLB). Kelurahan Pasirkaliki merupakan salah satu kelurahan di Kota Cimahi yang memiliki status gizi normal pada balita terendah (Dinkes Cimahi 2013). Oleh karena latar belakang di atas peneliti tertarik untuk mengetahui hubungan keragamanan pangan dengan status gizi pada anak balita di Kelurahan Pasirkaliki Kecamatan Cimahi Utara.

\section{BAHAN DAN METODE}

Rancangan dalam penelitian ini adalah penelitian cross sectional untuk melihat hubungan antara keragaman pangan dengan status gizi balita di Kelurahan Pasirkaliki, Cimahi Utara. Sumber data dalam penelitian ini didapatkan melalui data primer dan data sekunder. Data sekunder didapatkan untuk mengetahui data jumlah balita di setiap RW di Kelurahan Pasirkaliki. Data primer yang didapatkan meliputi data sosial demografi, keragaman pangan, dan antropometri (berat badan dan tinggi badan) dari 79 keluarga yang mempunyai balita.
Populasi penelitian ini adalah seluruh balita di kelurahan pasirkaliki yang memiliki balita dari 12 Rukun Warga (Desa). Adapun yang menjadi subjek penelitian ini adalah memenuhi kriteria sebagai berikut: keluarga yang mempunyai anak berusia dibawah 5 tahun, anak dalam keadaan sehat tidak mempunyai penyakit kronis, Ibu atau pengasuh bersedia menjadi sampel dan mengisi inform consent. Subjek dipilih dengan menggunakan metode simple random sampling, dengan tahapan sebagai berikut: peneliti mendapatkan daftar balita di kelurahan Pasirkaliki kemudian dilakukan random berdasarkan sampling frame yang telah di dapatkan dari tiap Posyandu sehingga terpilih 79 keluarga balita beserta cadangannya. Jika ibu atau balita tidak ada di rumah atau tidak memenuhi kriteria sampel maka akan dipilih balita dari cadangan yang terpilih diawal. Jika dalam satu keluarga memiliki lebih dari satu balita maka balita dengan umur tertua yang akan dijadikan responden.

Metode pengumpulan data pada penelitian ini adalah wawancara menggunakan kuesioner terstruktur untuk mendapatkan data sosial demografi dan data keragaman pangan melalui wawancara kepada ibu balita atau orang yang paling bertanggung jawab terhadap makanan yang dikonsumsi oleh anak balita. Tingkat sosial ekonomi didapatkan dengan menggunakan total pendapatan kemudian dibandingkan dengan Upah Minimum Regional (UMR) Kota Cimahi.

Wawancara menggunakan dietary diversity questionnaire yang diadaptasi dari FANTA Dietary Diversity Score Indicator Guide dilakukan untuk mendapatkan data skor keragaman pangan (FAO 2011). Wawancara akan dilakukan secara terstruktur kepada ibu balita/pengasuh yang tahu pasti makanan yang dikonsumsi oleh Balita sehari-hari. Wawancara ini dilakukan oleh enumerator yang sudah terlatih dalam mengukur asupan makanan. Food photograph digunakan sebagai media untuk menyamakan persepsi antara enumerator dan subjek yang di wawancara.

Pengukuran antropometri yang dilakukan pada penelitian ini meliputi pengukuran berat badan dan tinggi badan. Pengukuran dilakukan oleh enumerator yang terlatih dengan menggunakan alat yang telah di kalibrasi sebelumnya. Timbangan yang dipakai adalah timbangan digital merk Tanita dengan tingkat ketelitian $0.1 \mathrm{~kg}$. Timbangan diletakkan pada permukaan yang rata (indikator udara pada timbangan tepat berada di tengah). Balita ditimbang sebanyak dua kali dengan penimbangan ulang tidak lebih dari $0.1 \mathrm{~kg}$ dan hasil akhir diperoleh dari ratarata penimbangan. Jika perbedaan penimbangan lebih dari $0.2 \mathrm{~kg}$, pengukur dapat melakukan penimbangan ulang dan menghitung rata-rata menggunakan dua hasil penimbangan yang berdekatan.

Pengukuran tinggi badan bagi anak di atas 2 tahun menggunakan microtoise. Sedangkan pengukuran panjang badan bagi anak berusia kurang dari 2 tahun menggunakan infantometer. Panjang badan diukur menggunakan papan infantometer yang diletakkan 
pada permukaan yang rata. Pengukuran dilakukan minimal oleh 2 orang pengukur untuk menyesuaikan posisi anak dan memastikan akurasi pengukuran. Pengukur pertama memastikan posisi anak lurus 'Frankfrut plane' dengan kepala menempel pada bagian dinding/infantometer. Pengukur kedua memastikan badan menempel pada papan dan jari kaki menghadap ke atas dengan posisi tegak lurus dan menempel pada bagian skala ukur (papan yang bergerak). Setiap pengukuran dilakukan dua kali dan perbedaan dari dua pengukuran tidak lebih dari 0.1 $\mathrm{cm}$.

Pengolahan data meliputi editing, coding, entry dan cleaning. Data yang telah dikumpulkan diolah dengan menggunakan perangkat lunak komputer. Status gizi anak di bawah lima tahun dianalisis dengan menggunakan indeks antropometri berupa berat badan berdasarkan umur $(\mathrm{BB} / \mathrm{U})$, Berat badan berdasakan tinggi badan $(\mathrm{BB} / \mathrm{TB})$, dan tinggi badan berdasarkan usia (TB/U). Konversi data pengukuran antropometri dalam indeks z-score dilakukan dengan menggunakan WHO anthro 2005.

Skor keragaman pangan didapatkan melalui wawancara menggunakan dietary diversity questionnaire dengan menjumlahkan jumlah kelompok bahan makanan yang dikonsumsi oleh anak balita dari 7 kelompok makanan. Anak dengan jumlah skor $\geq 4$ (4 macam kelompok makanan) maka akan dikategorikan menjadi mengkonsumsi makanan yang beragam. Sedangkan anak dengan jumlah skor $<4$ maka akan dikategorikan menjadi mengkonsumsi makanan yang kurang beragam (WHO 2010).

Data berskala kategorik disajikan sebagai sebaran frekuensi (n, \%). Uji yang digunakan pada penelitian ini adalah uji chi-square dan uji fishers exact. Batas kemaknaan yang digunakan adalah $\mathrm{p}<0.05$ dengan derajat kepercayaan sebesar $95 \%$.

\section{HASIL}

Karakteristik Balita dan Ibu Balita. Sebagian besar Balita berjenis kelamin laki-laki sebanyak 43 orang $(54.4 \%)$ sedangkan perempuan sebanyak 36 orang (45.6\%). Mayoritas anak berusia 25-59 bulan (63.3\%), 6-12 bulan (13.9\%), dan 13-24 bulan (22.8\%). Terkait dengan Ibu Balita, sebanyak 48 orang (61.5\%) menyelesaikan pendidikannya hingga SMP sedangkan 30 orang $(38.5 \%)$ telah menyelesaikan pendidikan lebih dari 9 tahun yaitu lulus SMA Sederajat dan Sarjana. Sebanyak 68 Ibu (87.2\%) tidak bekerja sedangkan $10 \mathrm{Ibu}(12.8 \%)$ bekerja sebagai buruh, pegawai swasta dan berwirausaha. Adapun pekerjaan Ayah sebagian besar sebagai buruh pabrik (35\%). Pendapatan keluarga sebagian besar masih di bawah Upah Minimum Kota Cimahi $(<\mathrm{Rp}$. 2.275.000,-) yaitu sebanyak 51 Keluarga (65.4\%).

Status Gizi Balita. Gambar 1 menunjukkan status gizi balita, prevalensi balita kurang sebanyak $10.1 \%$, balita pendek sebanyak $21.5 \%$, dan balita kurus sebanyak 3.8\%. Berdasarkan cut-off public health problem dari WHO, prevalensi balita kurus di kelurahan pasirkaliki termasuk dalam kategori rendah $(<5 \%)$, prevalensi pendek termasuk dalam kategori medium (20.0-29.9\%) sedangkan berat badan kurang juga termasuk dalam kategori medium (10.0-19.9\%).

Gambar 2 menunjukkan bahwa balita yang mengalami pendek terbanyak pada usia 13-24 bulan (33.3\%), berat badan kurang pada usia 13-24 bulan (16.7\%) dan kurus juga pada usia 13-24 bulan (5.6\%).

Keragaman Pangan. Tabel 2 menunjukkan konsumsi pangan balita berdasarkan 7 kelompok bahan makanan yang didasari penuntun Infant And Young Children Feeding Practice (IYCF) dari WHO. Seluruh balita $(100 \%)$ mengkonsumsi bahan makanan serealia yang banyak mengandung karbohidrat seperti nasi, roti, mie, kentang, ubi jalar, dan ubi kayu. Sebagian besar balita namun tidak mengkonsumsi kacang-kacangan 58\%, sebaliknya sebagian besar balita $67.9 \%$ mengkonsumsi makanan yang mengandung protein hewani seperti daging sapi, ayam dan ikan. Sejalan dengan konsumsi protein hewani sebagian besar balita mengkonsumsi telur sebanyak $60.8 \%$. Namun lebih dari setengahnya balita (54.4\%) tidak mengkonsumsi buah dan sayur sumber vitamin A seperti labu kuning, pepaya, mangga, wortel sayuran berdaun hijau, dan lainnya. Begitu juga dengan konsumsi buah dan sayuran lainnya sebanyak $65.8 \%$ balita tidak mengkonsumsi (seperti apel, pisang, jeruk, melon, jambu, tomat, kembang kol, mentimun, tauge, dan lainnya).

Tabel 3 menunjukkan kesimpulan dari konsumsi bahan makanan anak Balita dimana 70.9\% anak mengkonsumsi makanan yang beragam. Sedangkan $23 \%$ anak balita tidak mengkonsumsi makanan yang beragam. Anak dikatakan mengkonsumsi makanan yang beragam jika dalam sehari mengkonsumsi

Tabel 1. Karakteristik balita dan ibu balita $(\mathrm{n}=79)$

\begin{tabular}{|c|c|c|}
\hline Karakteristik & $\mathrm{n}$ & $\%$ \\
\hline \multicolumn{3}{|l|}{ Jenis kelamin balita } \\
\hline Laki-laki & 43 & 54.4 \\
\hline Perempuan & 36 & 45.6 \\
\hline \multicolumn{3}{|l|}{ Usia balita } \\
\hline 6-12 bulan & 11 & 13.9 \\
\hline 13-24 bulan & 18 & 22.8 \\
\hline $25-59$ bulan & 50 & 63.3 \\
\hline \multicolumn{3}{|l|}{ Pendidikan ibu } \\
\hline$\leq 9$ tahun & 48 & 61.5 \\
\hline$>9$ tahun & 30 & 38.5 \\
\hline \multicolumn{3}{|l|}{ Pekerjaan ibu } \\
\hline Bekerja & 10 & 12.8 \\
\hline Tidak bekerja & 68 & 87.2 \\
\hline \multicolumn{3}{|l|}{ Pekerjaan ayah } \\
\hline PNS & 2 & 2.5 \\
\hline Karyawan & 21 & 26.6 \\
\hline Wirausaha & 16 & 20.5 \\
\hline Supir/ojeg & 9 & 11.4 \\
\hline Buruh & 28 & 35.4 \\
\hline Lainnya & 2 & 2.5 \\
\hline \multicolumn{3}{|l|}{ Penghasilan keluarga } \\
\hline$<$ Rp.2.275.000,- & 51 & 65.4 \\
\hline$\geq$ Rp.2.275.000,- & 27 & 34.6 \\
\hline
\end{tabular}




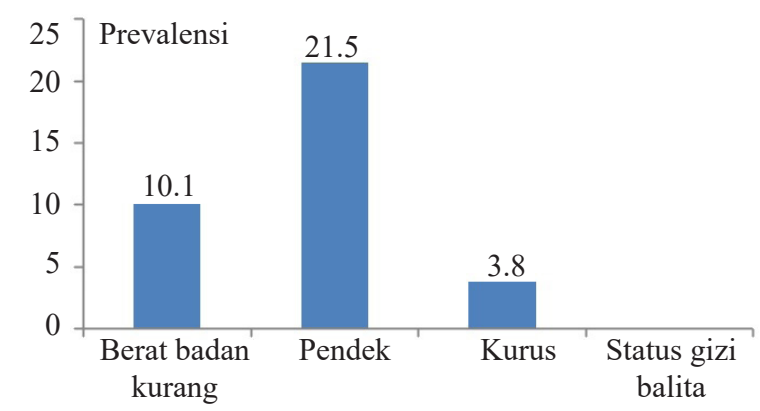

Gambar 1. Prevalensi masalah gizi pada balita

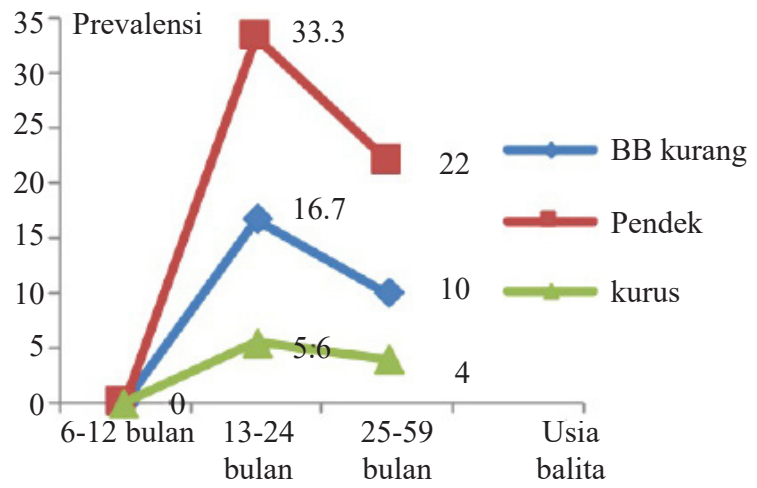

Gambar 2. Prevalensi kekurangan gizi pada balita berdasarkan usia

Tabel 2. Konsumsi pangan balita berdasarkan 7 kelompok bahan makanan

\begin{tabular}{lrr}
\hline Kelompok bahan makanan & $\mathrm{n}$ & $\%$ \\
\hline $\begin{array}{l}\text { Serealia } \\
\quad \text { Konsumsi }\end{array}$ & 79 & 100 \\
$\quad$ Tidak konsumsi & 0 & 0 \\
$\begin{array}{l}\text { Kacang-kacangan } \\
\quad \text { Konsumsi } \\
\quad \text { Tidak konsumsi }\end{array}$ & 33 & 41.8 \\
$\begin{array}{l}\text { Protein hewani } \\
\quad \text { Konsumsi }\end{array}$ & 46 & 58.0 \\
$\quad$ Tidak konsumsi & 53 & 67.1 \\
Telur & 26 & 32.9 \\
$\quad$ Konsumsi & & \\
$\quad$ Tidak konsumsi & 48 & 60.8 \\
$\begin{array}{l}\text { Buah dan sayur } \\
\text { sumber vitamin A }\end{array}$ & 31 & 39.2 \\
$\quad$ Konsumsi & & \\
$\quad$ Tidak konsumsi & & 45.6 \\
Buah dan sayur & 36 & 54.4 \\
lainnya & 43 & 34.2 \\
$\quad$ Konsumsi & & 65.8 \\
$\quad$ Tidak konsumsi & & \\
\hline
\end{tabular}

Tabel 3. Keragaman pangan anak balita

\begin{tabular}{lcc}
\hline Keragaman pangan & $\mathrm{n}$ & $\%$ \\
\hline Beragam & 56 & 70.9 \\
Tidak beragam & 23 & 29.1 \\
\hline
\end{tabular}

minimal 4 dari 7 grup bahan makanan yang ada. Nilai mean dan median skor keragaman pangan dalam penelitian ini adalah 4.3 dan 5.0.

Hubungan Keragaman Pangan dan Status Gizi Balita. Tabel 4 menunjukkan proporsi balita dengan berat badan kurang pada anak yang tidak mengkonsumsi makanan beragam sebesar 4.3\% sedangkan pada anak yang mengkonsumsi makanan beragam sebesar $12.3 \%$. Proporsi balita pendek pada anak yang tidak mengkonsumsi makanan beragam sebesar $21.7 \%$ sedangkan pada anak yang mengkonsumsi makanan beragam 21.4\%. Proporsi balita kurus pada anak yang mengkonsumsi makanan beragam sebanyak 3\%. Pada uji statistik fisher exact diketahui tidak ada perbedaan yang nyata antara keragaman pangan dengan ketiga indikator status gizi $(\mathrm{p}>0.05)$.

\section{PEMBAHASAN}

\section{Karakteristik Balita dan Ibu Balita.} Secara umum subjek pada penelitian ini berada di lingkungan sosial ekonomi menengah kebawah dilihat dari mayoritas pendidikan Ibu, pekerjaan ayah, dan pendapatan keluarga. Tingkat pendidikan akan mempengaruhi jenis pekerjaan dan mempengaruhi pada jenis pekerjaan maupun jumlah pendapatan. Data dari National Center for Children in Poverty (NCCP) tahun 2006 menunjukkan bahwa 82\% dari anak yang mempunyai orang tua dengan tingkat pendidikan kurang dari SMA, mempunyai pendapatan rendah (NCCP 2007). Pendapatan orang tua yang rendah dapat mempengaruhi akses anak terhadap makanan yang bergizi hingga mempengaruhi status gizinya. Penelitian sebelumnya menunjukkan adanya hubungan antara pendapatan keluarga dengan status gizi balita menggunakan indikator $\mathrm{BB} / \mathrm{TB}$ (Wirawan dan Rahmawati 2016). Peranan ibu bekerja akan sangat berpengaruh terhadap pola asuh anak, karena ibu yang tidak bekerja dianggap dapat memberikan pola asuh yang terbaik pada anak hingga mencapai status gizi yang optimal. Pada penelitian ini mayoritas ibu tidak bekerja, namun penelitian sebelumnya menunjukan tidak adanya hubungan antara status ibu bekerja dengan status gizi anak dan terdapat hubungan antara lama ibu bekerja dengan status gizi anak (Purnama 2012).

Tabel 4. Hubungan antara keragaman pangan dengan status gizi

\begin{tabular}{|c|c|c|c|c|c|c|}
\hline \multirow[t]{3}{*}{ Keragaman pangan } & \multicolumn{6}{|c|}{ Status gizi } \\
\hline & \multicolumn{2}{|c|}{ Kategori BB/U } & \multicolumn{2}{|c|}{ Kategori TB/U } & \multicolumn{2}{|r|}{ Kategori BB/TB } \\
\hline & $\begin{array}{l}\text { Berat badan } \\
\text { kurang n (\%) }\end{array}$ & $\begin{array}{l}\text { Normal p-value } \\
\mathrm{n}(\%)\end{array}$ & $\begin{array}{l}\text { Berat badan } \\
\text { kurang } \mathrm{n}(\%)\end{array}$ & $\begin{array}{l}\text { Normal p-value } \\
\mathrm{n}(\%)\end{array}$ & $\begin{array}{l}\text { Berat badan } \\
\text { kurang } \mathrm{n}(\%)\end{array}$ & $\begin{array}{l}\text { Normal p-value } \\
\mathrm{n}(\%)\end{array}$ \\
\hline Tidak beragam & $1(4.3)$ & $22(95.7) \quad 0.275$ & $5(21.7)$ & $18(78.3) \quad 0.976$ & $0(0)$ & $23(100)$ \\
\hline Beragam & $7(12.5)$ & $49(87.5)$ & $12(12.4)$ & $44(78.6)$ & $3(5.4)$ & $53(94.6)$ \\
\hline
\end{tabular}

*Uji Fisher's exact 
Dengan demikian diharapkan ibu yang bekerja dan tidak bekerja diharapkan tetap dapat memberikan pola asuh yang baik bagi anak.

Status Gizi Balita. Prevalensi balita kurang sebanyak $10.1 \%$, balita pendek sebanyak $21.5 \%$, dan balita kurus sebanyak $3.8 \%$. Berdasarkan cutoff public health problem, prevalensi balita kurus di kelurahan pasirkaliki termasuk dalam kategori rendah $(<5 \%)$, prevalensi pendek termasuk dalam kategori medium (20.0-29.9\%) sedangkan berat badan kurang juga termasuk dalam kategori medium (10.0-19.9\%). Dalam penelitian ini prevalensi balita pendek merupakan yang tertinggi dibandingkan dengan kedua indikator lainnya. Hal ini sejalan dengan hasil Riset Kesehatan Dasar tahun 2013 yang menunjukkan hasil prevalensi balita pendek yang cukup tinggi yaitu 37.2\% (Kemenkes RI 2013). Secara nasional, prevalensi berat-kurang pada tahun 2013 adalah 19.6\%. Jika dibandingkan dengan angka prevalensi nasional tahun 2007 (18.4\%) dan tahun $2010(17.9 \%)$ terlihat meningkat. Wilayah Jawa Barat sendiri memiliki prevalensi balita dengan berat badan kurang 15\%, balita pendek $30 \%$, dan balita kurus 10\% (Kemenkes RI 2013). Pada penelitian ini ditemukan prevalensi status gizi kurang di bawah nilai nasional maupun Jawa barat, namun data yang didapatkan konsisten dengan hasil Riskesdas 2013 bahwa prevalensi tertinggi adalah balita pendek diikuti dengan prevalensi balita dengan berat badan kurang, dan balita kurus.

Berdasarkan kerangka konsep dari UNICEF ada beberapa penyebab kekurangan gizi. Malnutrisi bukanlah masalah sederhana dengan solusi tunggal dan sederhana. Menurut kerangka konsep ini ada penyebab langsung, penyebab tidak langsung dan penyebab dasar dari kekurangan gizi. Penyebab langsung mempengaruhi individu, penyebab tidak langsung berhubungan dengan keluarga, dan penyebab dasar terkait dengan masyarakat dan bangsa. Ada dua penyebab langsung malnutrisi yaitu asupan yang tidak memadai dan adanya penyakit menular. Di negara berkembang, penyakit menular, seperti penyakit diare dan infeksi saluran pernapasan akut (ISPA), bertanggung jawab dalam sebagian besar masalah kesehatan gizi (UNICEF 2011). Selain itu kejadian stunting juga banyak berkaitan dengan status gizi ibu saat hamil, pengetahuan ibu, dan sanitasi dan higiene dari lingkungan yang ditempati.

Balita dengan status gizi pendek/stunting terbanyak pada usia $13-24$ bulan (33.3\%), berat badan kurang pada usia 13-24 bulan (16.7\%) dan kurus juga pada usia 13-24 bulan (5.6\%). Permasalahan kekurangan gizi di Indonesia yang menjadi perhatian utama saat ini adalah prevalensi balita pendek karena Indonesia masih memiliki prevalensi balita stunting diatas ambang batas WHO $(>20 \%)$. Prevalensi balita pendek dalam penelitian ini masih diatas ambang batas masalah kesehatan masyarakat dari WHO. Dalam hasil penelitian ini prevalensi balita pendek meningkat dengan seiring bertambahnya usia. Balita pendek merupakan suatu kondisi kekurangan gizi yang bersifat kronis.

Berdasarkan penelitian Shrimpton dan Kachondham tahun 2003 z-skor terendah untuk $\mathrm{TB} / \mathrm{U}$ terjadi pada usia 22-24 bulan (Shrimpton dan Kachondham 2003). Hasil penelitian kami juga menunjukan prevalensi balita pendek tertinggi di usia 12-24 bulan sejalan dengan hasil penelitian yang dilakukan oleh Wirawan di Kota Malang pada tahun 2016 (Wirawan dan Rahmawati 2016). Berkaitan dengan hal itu pencegahan kejadian balita pendek harus dilakukan sejak awal kehamilan hingga sebelum usia 2 tahun yang disebut sebagai 1,000 hari pertama kehidupan (Prentice et al. 2018). Balita pendek mengindikasikan akumulasi efek jangka panjang dari kekurangan gizi, sehingga balita pendek tidak hanya sebagai indikator untuk kekurangan status gizi namun juga menunjukkan ketidakcukupan kebutuhan dasar akibat dari kemiskinan (Gross et al. 2000).

Prevalensi berat badan kurang dapat meningkat pada usia 12 bulan hingga mencapai 24 bulan karena pada usia tersebut dapat disebabkan oleh pemberian makanan pendamping ASI yang kurang tepat baik dari segi jumlah, jenis, bentuk, kurangnya higiene dan sanitasi, pola asuh makan dan penyapihan ASI yang dini (WHO 2010). Berat badan kurang dapat disebabkan oleh permasalahan gizi yang bersifat akut sedangkan balita pendek disebabkan oleh masalah gizi yang bersifat kronis (Gibson 2005).

Keragaman Pangan Balita. Sebanyak 65.8\% balita pada penelitian ini tidak mengkonsumsi buah dan sayuran (seperti apel, pisang, jeruk, melon, jambu, tomat, kembang kol, mentimun, tauge, dan lainnya). Data Riskesdas tahun 2013 menunjukkan bahwa rerata Nasional konsumsi cukup sayur dan buah di Indonesia adalah 6.5\% (Kemenkes RI 2013).

Pada penelitian ini dapat dilihat bahwa anak Balita lebih banyak mengkonsumsi makanan sumber karbohidrat dan sumber protein hewani. Berkaitan dengan hal ini diharapkan anak Balita dapat mencukupi asupan zat gizi makro, namun asupan sayuran dan buah yang kurang berhubungan dengan pemenuhan zat gizi mikro. Lebih besarnya prevalensi pendek pada penelitian ini dibandingkan dengan kedua indikator lainnya dapat berhubungan dengan pemenuhan zat gizi mikro. Balita pendek tidak semata-mata disebabkan karena ketersediaan 
dan asupan zat gizi makro, balita pendek lebih disebabkan karena masalah kekurangan zat gizi mikro dimana $65.8 \%$ anak tidak mengkonsumsi buah dan sayuran (Souganidis 2012). Anak dikatakan mengkonsumsi makanan yang beragam jika dalam sehari mengkonsumsi minimal 4 dari 7 grup bahan makanan yang ada. Nilai mean dan median skor keragaman pangan dalam penelitian ini adalah 4.3 dan 5.0. Nilai yang sama didapatkan dari penelitian yang dilakukan di Jawa Tengah dan Jawa Barat pada keluarga petani teh yaitu median skor keragaman pangan mencapai 4.0 (Savica 2016) demikian juga dengan rata-rata keragaman pangan pada anak di Ghana sebesar 4.6 (Nti 2011).

Hubungan antara Keragaman Pangan dengan Status Gizi Balita. Penelitian Sukma menunjukkan beragamnya pangan yang dikonsumsi sangat penting untuk diukur agar dapat menilai kualitas konsumsi pangan. Keragaman pangan dapat ditentukan dari item pangan yang dikonsumsi atau penjumlahan kelompok pangan yang dikonsumsi (Sukma 2014). Dietary Diversity Score (DDS) atau skor keragaman pangan merupakan salah satu cara pengukuran kualitas konsumsi pangan. Menurut FAO, metode DDS merupakan metode sederhana yang mudah dilakukan namun sangat efektif untuk mengukur perbedaan keragaman konsumsi pangan pada tingkat rumah tangga maupun individu (FAO 2011). Dalam penelitian ini tidak ditemukan hubungan antara keragaman pangan dengan status gizi menggunakan indikator $\mathrm{BB} / \mathrm{U}, \mathrm{TB} / \mathrm{U}$, dan $\mathrm{BB} /$ TB. Hal yang sama ditemukan oleh Sie A et al. di Burkina Faso bahwa tidak ada hubungan antara keragaman pangan dengan status gizi menggunakan indikator BB/TB (Sie et al. 2018). Hasil yang sama menunjukkan bahwa keragaman pangan tingkat individu bukan merupakan prediktor status gizi balita di Kenya (Zipporah et al. 2018). Penelitian lain yang dilakukan di Malang menunjukkan ada hubungan antara keragaman pangan dengan Z-skor BB/TB (Wirawan dan Rahmawati 2016).

Prevalensi balita dengan status gizi kurang dan pendek pada anak yang mengkonsumsi makanan beragam lebih besar dibandingkan pada anak yang mengkonsumsi makanan tidak beragam. Hal ini mungkin dikarenakan pada anak yang mengkonsumsi makanan yang beragam sebagian besar $(57.6 \%)$ mempunyai asupan energi yang kurang. Pada penelitian ini dilakukan pengukuran keragaman pangan dengan menggunakan metode Individual Dietary Diversity Score (IDDS). Kelemahan dalam penggunaan dietary diversity skor yaitu hanya menghitung jumlah jenis kelompok makanan yang dikonsumsi tanpa mempertimbangkan porsi dan jumlah yang dimakan. Sehingga ada kemungkinan subjek mengkonsumsi makanan yang beragam namun tidak dalam kuantitas yang cukup.

Prevalensi balita dengan berat badan kurang, pendek, dan kurus pada penelitian ini adalah $10.1 \%$, $21.5 \%$, dan $3.8 \%$. Berdasarkan cut-off public health problem significance, prevalensi balita kurus di kelurahan pasirkaliki termasuk dalam kategori rendah $(<5 \%)$, prevalensi pendek termasuk dalam kategori medium (20.0-29.9\%) sedangkan berat badan kurang juga termasuk dalam kategori medium (10.0-19.9\%). Prevalensi tertinggi balita dengan berat badan kurang, pendek dan kurus berada di usia 13-24 bulan. Seluruh balita (100\%) mengkonsumsi bahan makanan serealia, $67.9 \%$ mengkonsumsi makanan yang mengandung protein hewani dan $60.8 \%$ mengkonsumsi telur. Namun $58 \%$ balita tidak mengkonsumsi kacang, $54.4 \%$ balita tidak mengkonsumsi buah dan sayur sumber vitamin A, dan $65.8 \%$ balita tidak mengkonsumsi buah dan sayuran lainnya. Secara keseluruhan sebanyak $70.9 \%$ anak balita mengkonsumsi makanan yang beragam. Tidak ada hubungan yang bermakna antara konsumsi keragaman pangan dengan status gizi anak Balita di wilayah Kelurahan Pasirkaliki Kota Cimahi.

Keragaman pangan penting untuk memenuhi kebutuhan zat gizi terutama zat gizi mikro. Balita disarankan untuk mengkonsumsi buah dan sayur sumber vitamin A serta buah dan sayuran lainnya. Untuk mendapatkan status gizi yang optimal pada anak di bawah lima tahun disarankan untuk mengkonsumsi makanan yang beragam dengan jumlah porsi yang sesuai dengan pedoman gizi seimbang. Dibutuhkan penelitian lebih lanjut mengenai keragaman pangan, asupan zat gizi dengan status gizi anak untuk menyempurnakan hasil pada penelitian ini.

\section{UCAPAN TERIMA KASIH}

Terima kasih kepada seluruh pihak di Kelurahan Pasirkaliki yang telah terlibat dalam pengumpulan data pada penelitian ini. Penelitian ini dilaksanakan dengan dana yang diberikan oleh Poltekkes Kemenkes Bandung.

\section{DAFTAR PUSTAKA}

Dinas Kesehatan Kota Cimahi. 2013. Profil Kesehatan Kota Cimahi Tahun 2013. Tersedia di: http://www.depkes. go.id/resources/download/profil/PROFIL_KAB KOTA_2013/3277_Jabar_Kota_Cimahi_2013.pdf [Tanggal diakses: 12 November 2018]

Fauzia S, Rahayuning DP, Widajanti L. 2016. Hubungan keberagaman jenis makanan dan kecukupan gizi dengan indeks massa tubuh (Imt) pada ibu menyusui Di Wilayah Kerja Puskesmas Kedungmundu Kota Semarang Tahun 2016. Jurnal Kesehatan Masyarakat 4:233-242.

[FAO] Food Agriculture Organization. 2011. Guidelines for Measuring Household and Individual Dietary Diversity. ROMA;FAO. ISBN 978-92-5-106749-9. Tersedia di: www.foodsec.org [Tanggal diakses: 24 Juli 2018]

Gazali AP. 2015.Keragaman Konsumsi Pangan Dan Hubungannya Dengan Status Gizi Pada Orang Dewasa Di Perkotaan (Skripsi). Bogor, Indonesia: Departemen Gizi Masyarakat Fakultas Ekologi Manusia Institut Pertanian Bogor.

Gibson RS. 2005. Principles of Nutritional Assessment. Dunedin: Oxford University Press 
Gross R, Schoeneberger, H, Pfeiffer H, Hans-Joachim AP. 2000. The Four Dimensions of Food and Nutrition Security:Definition and concepts. Rome: FAO. Tersedia di: http://www.fao.org/elearning/course/fa/en/pdf/p-o1_ rg conceptt.pdf [Tanggal diakses: 24 Juli 2018]

Kementrian Kesehatan Republik Indonesia.2013. Riset Kesehatan Dasar. Jakarta: Lembaga Penerbitan Badan Litbangkes.

Kementerian Kesehatan Republik Indonesia. 2014. Peraturan Menteri Kesehatan Republik Indonesia Nomor 41 Tahun 2014 Tentang Pedoman Gizi Seimbang. Jakarta: Kemenkes RI.

Kementerian Kesehatan Republik Indonesia, Direktorat Gizi Masyarakat. 2017. Buku Saku Pemantauan Status Gizi Tahun 2017. Jakarta: Kementerian Kesehatan.

Kementerian Perencanaan Pembangunan Nasional (BAPPENAS), United Nations Children's Fund (UNICEF). 2017. Laporan Baseline SDG tentang Anak-Anak di Indonesia. Jakarta: BAPPENAS dan UNICEF.

[NCCP] National Center for Children in Poverty. 2007. Parents' Low Education Leads to Low Income, Despite Full-Time Employment. New York: Columbia University.

Nti CA. 2011. Dietary diversity is associated with nutrient intakes and nutritional status of children in ghana. Asian Journal of Medical Sciences 2:105-109.

Onis MD, Blössner M. 2000. Prevalence and trends of overweight among preschool children in developing countries. The American Journal of Clinical Nutrition 72:1032-1039.

Prentice AM, Kate AW, Gail RG, Landing MJ, Sophie, EM, Anthony JF. 2013. Critical windows for nutritional interventions against stunting. Am J Clin Nutr 97:911-8.

Purnama A. 2012. Hubungan antara status ibu bekerja atau ibu tidak bekerja dengan status gizi anak balita di kecamatan medan tembung [Tesis]. Medan, Indonesia: Universitas Sumatera Utara.

Rah JH, Akhter N, Semba RD, de Pee S, Bloem MW, Campbell AA.2010. Low dietary diversity is a predictor of child stunting in rural Bangladesh. European Journal of Clinical Nutrition 64:1393-1398.

Ruel M, Minot N, Smith. 2004. Patterns and determinants of fruit and vegetable demand in developing countries: a multi-country comparison. Paper prepared for the Joint WHO/FAO Workshop on Fruit and Vegetables for Health. Kobe: Japan.
Savica. 2016. Evaluation Report: Incorporating Nutrition in the Agriculture Sector Increases Dietary Diversity among Tea Farmers in West and Central Java, Indonesia.

Shrimpton R, Kachondham Y. 2003. Analysing the Causes of Child Stunting in DPRK.UNICEF. Tersedia di: http:// www.unicef.org/dprk/further_analysis.pdf [Tanggal diakses: 24 Juli 2018]

Sie A, Tapsoba C, Dah C, Ouermi L, Zabre P, Barnighause T, Arzika AM, Lebas E, Snyder BM, Moe C, Keenan, JD, Oldenburg CE. 2018. Dietary diversity and nutritional status among children in rural Burkina Faso. Int Health 10:157-162. DOI:10.1093/inthealth/ihy016

Souganidis E.2012.The relevance of micronutrients to the prevention of stunting. Sight and Life 26:10-18.

Sukma M. 2014. Keragaman Konsumsi Dan Ketahanan Pangan Serta Food Coping Strategy Pada Masyarakat Adat Kasepuhan Ciptagelar [Skripsi]. Bogor, Indonesia: Departemen Gizi Masyarakat Fakultas Ekologi Manusia Institut Pertanian Bogor.

Susilowati, Kuspriyanto. 2016. Gizi dalam Daur Kehidupan. Bandung: Refika Aditama.

Taruvinga A, Muchenje V. 2013. Determinants of rural household dietary diversity: The case of Amatole and Nyandeni districts, South Africa. International Journal of Development and Sustainability 2:2233-2247.

[UNICEF] United Nation Children's Fund. 2011. Understanding Malnutrition Module 3. New York: UNICEF.

Wirawan NN, Rahmawati W. 2016. Ketersediaan dan keragaman pangan serta tingkat ekonomi sebagai prediktor status gizi balita. Indonesian Journal of Human Nutrition 3:80- 90.

[WHO] World Health Organization. 2010. Indicators for assessing infant and young child feeding practices part 3: country profiles. Geneva: WHO Press.

Zipporah NB, Moses M, Robert MK, Richard M, Yeri K, Lydia UK. 2014. Food insecurity and not dietary diversity is a predictor of nutrition status in children within semiarid agro-ecological zones in Eastern Kenya. Journal of Nutrition and Metabolism 2:1-9. 